\title{
Shaping the Spirituality of Communion in Church Communities
}

\author{
MIECZYS ŁAW POLAK \\ Adam Mickiewicz University in Poznań \\ mpolak@amu.edu.pl, ORCID: 0000-0003-3381-189X
}

\begin{abstract}
The activity of the Church results from its identity, and one constitutive element of this identity is the dimension of community. It is expressed, above all, by shaping the spirituality of communion in church communities. This spirituality has its foundations in the communion character of the presbyter's pastoral ministry and refers to the gospel commandment of love. It is shaped by Christian prayer centered on the Eucharist. The spirituality of communion built upon such foundations should permeate church community structures, which are made up, first and foremost, by parishes. On their own, parishes are not able to pass on the experience of church communion. Only by being infused with the spirituality of communion can they become spaces for experiencing the community dimension of the Church's life.
\end{abstract}

Keywords: community, spirituality, presbyter, parish

According to St. John Paul II, the basis for renewing church communities is to shape "the spirituality of communion" (cf. NMI, 43). It is all the more necessary since, as noted by Pope Francis, the call to renew the communion nature of these communities has not yet brought sufficient fruit, thanks to which they would be closer to people and would constitute environments for living communion and participation. For this reason, some of the baptized do not feel that they belong to the Church (cf. EG, 28 and 63). The presbyter's pastoral care for shaping the spirituality of communion in the community is one of his most important pastoral tasks. It results from the serving character of the ministerial priesthood towards the common priesthood of all the baptized. This article is an attempt to show fundamentals, principal ways and structures shaping and expressing the church spirituality of communion.

\section{Communion Character of the Presbyter's Pastoral Identity}

John Paul II described shaping the spirituality of communion in the Church as making the Church "the home and the school of communion." He said: "To make the Church the home and the school of communion: that is the great challenge facing 
us in the millennium which is now beginning, if we wish to be faithful to God's plan and respond to the world's deepest yearnings" (NMI 43). This task, undoubtedly, is inscribed in the pastoral identity of the modern presbyter and belongs to his main tasks. ${ }^{1}$ The foundations of this commitment arise from the "relational" nature of presbyterian identity $(P D V, 12)$. This identity is included in the dynamics of the Trinitarian relationship as the official priesthood remains in a genetic relationship with the salvific mystery of God the Father's love, the grace of the Incarnate Son Jesus Christ and the bestowal of unity in the Holy Spirit. ${ }^{2}$ The presbyter's communion reference to the Holy Trinity, which is the supernatural source of his ministry and life, should be experienced by him in an internal and personal way and with awareness that the gift associated with this relationship is a service to the Church so that he could be for each and every one "a sign and an instrument of communion with God and of unity among all men" $(L G, 1)$.

Bonds connecting members of church communities cannot be limited to legal regulations or juridical systems and to links of sociological or psychological nature. As soon as the grace of the sacrament of baptism is received, man becomes implanted in Christ. He participates is Jesus' anointing with the Holy Spirit, which is the basis of Christian identity.

Unity among Christians, as John Paul II explains, is derived from unity of Christians with Christ, since all Christians are all shoots of one Vine, that is, Christ himself. Jesus shows this unity as a miraculous reflection and mysterious participation in love that unites the Father, the Son and the Holy Spirit. And He asks for this unity in His prayer: "That all of them may be one, Father, just as you are in me and I am in you. May they also be in us so that the world may believe that you have sent me (Jn. 17:21)" (CHL, 18).

Hierarchical communion established by Christ and on the strength of special sacramental consecration is an institutional safeguard for the presence in human history of elementary Christian communion, which is a sign and instrument of salvation for the world. ${ }^{3}$

It should be emphasized once more that, contrary to linguistic habits favoring distinctive rather than co-defining terminology (e.g. hierarchy and laity, clergy and laity), the starting point for a proper understanding of the communion function of the church hierarchy in relation to the rest of the community of the People of God is the truth of the basic equality of all the baptized, bonded together in brotherhood in Christ. The Second Vatican Council teaches,

\footnotetext{
Cf. Polak, Prezbiterologia pastoralna, 108-135.

Cf. TE, 3-11; Gąsecki, "Prezbiter," 13-14.

Cf. John Paul II, "Więzi prezbiterów z innymi wiernymi," 344.
} 
that although priests in the New Testament, by virtue of the sacrament of priesthood, perform among and for the People of God a very sublime and necessary function of father and teacher, together with all the faithful they are the Lord's disciples and participants of His Kingdom thanks to the grace of the calling God. For with all those reborn in the water of baptism, presbyters are brothers among brothers, as members of one and the same Body of Christ, whose building is entrusted to all people $(P O, 9)$.

This means that the internal life of the Church should be shaped by a communicative, participatory and dialogical style of respect, trust and friendship. Church fraternal unity, however, cannot be understood in the sense of the fraternite of the Great French Revolution. This unity does not create itself and does not come about solely through fraternal dialogue. It assumes reconciliation, which, ultimately, is a gift of Christ's Redemption freeing from culpable acts. This gift, which cannot be deduced from the immanence of this world, is entrusted to the church hierarchy. ${ }^{4}$ Hence, its ministry is constitutive of church communion. Brotherhood in the Church cannot exist without spiritual fatherhood. It includes auctoritas in the original sense of the word, that is, as augere - to increase, and as an author - the word for one who multiplies. Hierarchical authority should not suppress life, but sow and multiply it. ${ }^{5}$

\section{Love as the Basis of Church Communion}

Taking into account the above arrangement, the building of the Church as "the home and the school of communion" should by primarily guided by a commandment which Jesus refers to as "my commandment" (cf. Jn. 15:12). He also calls it "a new commandment:" "A new commandment I give to you, that you love one another just as I have loved you" (Jn. 13:34). The commandment to love God above all, and a neighbour as oneself, appears already in the Old Testament (cf. Deut. 6:5 and Lev. 19:18). However, Jesus makes a major reinterpretation of this commandment, strongly emphasizing the interdependence of its both parts, since you cannot love God without loving man. One love requires another in such a close-knit way that a statement about the love of God becomes a lie if man closes himself to his neighbour or downright hates him (cf. 1 Jn. 4.20). The most important fact, however, is that in the understanding of Christ, love of one's neighbour is the most credible sign of belonging to Him: "By this all men will know that you are my disciples, if you love one another" (Jn. 13:35). What is more, Jesus shows Himself as a living example and measure of the love that should characterize His disciples. At the same time, $\mathrm{He}$

\footnotetext{
Cf. Biela, "Prezbiterat w służbie komunii," 41-43.

Cf. Kasper, Kościół katolicki, 604-605.
} 
presents Himself as the source of this love, as a "vine," which is the kind of love that bears fruit in His followers - "vine branches" (cf. Jn. 15:5). Hence the call: "Remain in my love!" (Jn. 15:9). Presbyterian communion service is closely linked to this Christ's appeal. ${ }^{6}$ As a consequence, wherever man and a Christian are shaped, where families and communities are established, the spirit of communion must be promoted before concrete communion-forming initiatives are undertaken.

The spirituality of communion, as John Paul II explains, is, above all, a look fixed on the Mystery of the Holy Trinity, which resides in us and whose splendour should also be seen in the faces of brothers living around us. The spirituality of communion is also the ability to feel the bond with the brother in faith thanks to the deep unity of the mystical Body, and thus perceiving him as «someone close», which allows to share his joy and suffering, guess his desires and satisfy his needs, offer him a true and deep friendship. The spirituality of communion is also the ability to see in the other man what is positive and what should be accepted and seen as God's gift: a gift not only for the brother who directly received it, but also a "gift for me». Finally, the spirituality of communion is the ability to «make room» for a brother, to jointly «carry burdens». Let us not delude ourselves - the Pope concludes - without such a spiritual attitude, external communion tools would be of little use. They would become soulless mechanisms, rather appearances of communion than ways of expressing and developing it (NMI, 43).

\section{Communion Logic of Christian Prayer}

In the Acts of the Apostles, we read that after the ascension of the Risen Christ, the Apostles gathered in the Cenacle and "all joined together constantly in prayer, along with the women, and Mary the Mother of Jesus, and with His brothers" (cf. Acts 1:12-14). This biblical image of the church communio fidelium, which was to be revealed to the world on the day of Pentecost along with the reception of the Holy Spirit, shows that the basic feature of being open to communion spirituality is "remaining in prayer"'. The prayer unity of the original community, just like all subsequent generations in the Church, not only expresses spiritual communion, but also creates, deepens and strengthens it. This prayer unity allows to overcome differences and divisions that inevitably arise between people. For example, the Acts of the Apostles mention that also women gathered in the Cenacle for prayer as they too were to receive the Holy Spirit on the day of Pentecost. Thanks to it, already at the starting point, the church community vividly experienced the truth which the Apostle Paul will announce to the world a little later: "there is neither male nor female, for you

Cf. John Paul II, “Kościół tajemnicą," 99-102. 
are all one in Christ" (cf. Gal. 3:28)..$^{7}$ After the Descent of the Holy Spirit, these basic features of the church community became even more solid and distinct, which is clearly expressed by the following testimony, recorded by the author of the Acts: "All the believers were one in heart and mind" (Acts 4:32). The foundation of this unity was still nothing but "remaining in prayer," which strengthened the community, especially in difficult moments. ${ }^{8}$

Taking all of this into account, John Paul II in the apostolic letter Novo millennio ineunte calls upon priests to make education for prayer a key element of the pastoral programme of promoting the spirituality of communion.

Our Christian communities, says the Pope, must become genuine «schools» of prayer, where the meeting with Christ is expressed not just in imploring help but also in thanksgiving, praise, adoration, contemplation, listening and ardent devotion, until the heart truly «falls in love». Intense prayer, yes, but it does not distract us from our commitment to history: by opening our heart to the love of God it also opens it to the love of our brothers and sisters, and makes us capable of shaping history according to God's plan (NMI, 33).

The communion logic of Christian prayer can be taught in various ways. However, this can be the most fully and fruitfully achieved in the liturgy, which - as stated by the Second Vatican Council - is the summit towards which the Church's activity proceeds and the source from which all its power stems (cf. SC, 10). During the postconciliar period, church ministry emerged as more mature in celebrating the sacraments, especially the Eucharist. One should continue to move in this direction, attaching particular importance to the liturgical celebration of the Sunday Eucharist. Presbyters, genuinely concerned about promoting the spirituality of communion, should ensure that participation in the Eucharistic prayer gathering becomes for every baptized person "the heart of Sunday" (cf. NMI, 35).

The Sunday Eucharist, as taught by John Paul II, which every week gathers Christians together as God's family round the table of the Word and the Bread of Life, is also the most natural antidote to dispersion. It is the privileged place where communion is ceaselessly proclaimed and nurtured. Precisely through sharing in the Eucharist, the Lord's Day also becomes the Day of the Church, when she can effectively exercise her role as the sacrament of unity (NMI, 36).

This implies an integral Eucharistic formation of the faithful, taking into account not only the vertical dimension of the Eucharist, but also its horizontal dimension: "The Eucharist is never just doing something in two, a dialogue between Christ and

John Paul II, “U źródeł," 103-106.

8 Cf. John Paul II, “Kościół jako komunia," 107-110. 
me. Eucharistic communion seeks to completely transform one's life. It destroys the entire «I» of man and creates a new «we». Communion with Christ is necessarily communication with all who are one." Hence, those who do not celebrate the Eucharist together only create its caricature. The Eucharist is celebrated either with one Christ and thus with the whole Church, or it is not celebrated at all. Whoever seeks only oneself in the Eucharist, who, in her and through her, does not join the whole Church, going beyond oneself, destroys her communion-forming power for oneself and for others. ${ }^{10}$

\section{Communion Character of Church Structures}

The pastoral primacy of promoting the spirituality of communion does not by any means disregard its institutional framework. This applies especially to the elementary pastoral structure, which is the parish. Its creation has its source and justification in the communion norm of evangelization, formulated by Christ himself, according to which the shepherd should know his sheep and the sheep should know their shepherd (cf. Jn. 10:14). However, the evangelistic "parish principle"11 cannot be absolutized. Yet, on the other hand, one cannot fail to notice and underestimate the fact that it has been for centuries an undeniably main and historically proven form of realizing God's work of salvation in the world. What is more, the Magisterium of the Church is convinced that Christians of tomorrow will also be able to experience the religious depth of knowing and experiencing the communion mystery of the Church nowhere else but in its parish context.

We should all discover, through faith - as John Paul II appeals - the true face of the parish, which is the very «mystery» of the Church that exists and operates in it. For the parish, although sometimes impoverished in terms of people and means, sometimes dispersed in vast areas, or lost in the populous, chaotic districts of large metropolises, is never simply a structure, a territory, a building, but rather «God's family animated by the spirit of unity», «a family fraternal and hospitable home», «a community of the faithful» $(\mathrm{CHL}, 26){ }^{12}$

Although it is not sufficiently justified to recognize the Cassandra's foreseeing that presages the twilight of the parish as a basic communion structure, one cannot ac-

\footnotetext{
Cf. Ratzinger, Pielgrzymująca wspólnota wiary, 69-70.

Ratzinger, Pielgrzymująca wspólnota wiary, 95.

Cf. Rahner, "Friedliche Erwägungen," 169-198.

Cf. Pannet, La paroisse de l'avenir, 159-171.
} 
cept peremptory claims that this institution, although historically and civilizationally conditioned, can safely continue its mission in the current formula. ${ }^{13}$ The crisis of the traditional territorial parish began as early as in the nineteenth century with industrialization processes and the demographic expansion of urban clusters. In the urbanized area, parish ministry was no longer able to go beyond the framework of interim satisfaction of religious needs of the faithful. Wider and more fruitful pastoral activity was out of question. Countermeasures taken (e.g. dividing parishes, increasing the number of curates, building more capacious temples, establishing parishes run by religious orders, etc.), though indispensable, did not solve the problem. They did not create a more significant potential that would exert direct impact.

The acceleration of the dynamism of socio-cultural changes that occurred in the last century has deepened the destructive impact of urbanization processes on traditional parish ministry. These changes - experienced by the current generation - are taking place in a historically new context of upsetting clearly defined cognitive and axiological criteria, social differentiation, deinstitutionalisation of life, ideological pluralism and postmodern secularization. In these conditions, the parish, especially in large urban agglomerations, faces more and more difficulties in preserving the face of a coherent and internally strong social unit. It does not cover all social activities of the faithful, because a large part of them takes place outside the parish. What is more, the metropolitan environment no longer binds residents through personal ties, but creates specialized organizations and associations that act as mediators between individual units and institutions. This process is accompanied by the formation of attitudes of individualism and utilitarianism, which typically manifests itself on being focused on the private sphere of life. Under these circumstances, parishes in large cities are increasingly losing their traditional profile of local communities, becoming - like other institutions - a kind of agency specialized in the provision of religious services.

Also the religious life of the faithful acquires a specialization-like character. Religious practices of urban parishioners constitute a separate area of their life activity, which is not superimposed on other activities. Social relations that occur between priests and the faithful and between the faithful and the parish usually adopt an indirect and secondary nature. Parish priests - quite often - appear to the faithful as anonymous church officers with whom only occasional and sporadic contacts are made. In fact, the parish is contacted only by those who need it under certain life circumstances. The number of parishioners who cease to identify themselves with the parish is also growing, though they still retain some sense of religious solidarity in the global ecclesial community. They lack external stimuli in the form of pressure from public opinion, environment habits that in a traditional parish, integrated with 
the local community, fostered the cultivation of religious practices and compliance with the rules of Christian customs. ${ }^{14}$

The outlined state of affairs caused some sociologists and theologians to make radical statements about the imminent end of the parish as the basic structure of church communion. ${ }^{15}$ As it is known, the Magisterium of the Church does not share this opinion. In its judgment, the parish system of evangelization in the history of the Church has always responded creatively to new challenges provoked by subsequent sociocultural changes. Therefore there are no reasons to doubt that the Church will be able to overcome the current impasse in which it is found.

The parish - as we read in the apostolic exhortation Evangelii gaudium - has great flexibility, it can take very different forms which require openness and missionary creativity on the part of the parish priest and community. Although it is certainly not the only institution of evangelization, if it maintains the ability to constantly reform and adapt itself, it will continue to be «the Church living in the midst of the homes of her sons and daughters» $(E G, 28)$.

In fact, the awareness of the need to properly modify the functioning of the parish, according to the requirements of the modern civilization situation, had already appeared in the early stages of the currently growing parish pastoral crisis. This can be demonstrated by numerous proposals for reconstructing the model of a territorial parish formulated over the last century. ${ }^{16}$ Although they were partial and fragmentary in character, at the end of the day, they gave an impulse to develop a more integrated and deepened concept, above all, in the light of the ecclesiology of communion of the Second Vatican Council and the official postulates of modernization of the parish system formulated on the pages of recent pastoral documents of the Magisterium of the Church. The most significant and constructive are those indications that express the truth that the parish - like the whole Church - becomes "the home and the school of communion" based on a supernatural gift. In a fundamental dimension, a religious community is God's gift. For this reason, John Paul II in the pastoral programme of "new evangelization" stresses the importance of the principle of the priority of grace (cf. NMI, 38). This principle, when applied to the parish, requires prioritizing valuation of the basic evangelizing functions of the Church's mission, that is, the so-called "common ministry," focused on the proclamation of the word of God, on the presence in the mystery of the liturgy of the saving Passover of Jesus Christ and on the diakonia of love. "For every community to be Christian - as John Paul II explains - it must live in Christ by listening to the word of God, by prayer

14 Cf. Makowski, "Postulat odnowy parafii," 187-189.
15 Cf. Goddijn - Goddijn, Sichtbare Kirche, 170.
16 Cf. Piwowarski, "Próby rekonstrukcji," 1311-1320. 
centered around the Eucharist, by communion expressed in the unity of heart and spirit, and by sharing goods according to the needs of its members" (RMi, 51).

This supernatural pastoral potential, not subject to any impoverishment in the course of transformation, is currently waiting for revival and animation. For many centuries, though, its saving dynamism was not sufficiently used. The civilization harmony between the parish community and the local community meant that the secondary functions of the parish, that is all the secular influences of the Church, favoured the discipline not only of sacramental life, but also of postulated moral attitudes and behaviour. Under these circumstances, it was easy to settle for a massive, passive form of participation in the life of the Church, a form in a way inherited, resulting from the strong establishment of religiousness in social tradition and custom. Such a state of affairs is now out of question. In this perspective, the transformations that took place as a result of civilization processes disintegrating the natural foundation of the parish community can be regarded as downright providential. They helped to understand the truth that without a definite return to the sources of the supernatural power of the Church, the parish cannot function as "the home and the school of communion." ${ }^{17}$

It is a fact that the vertical dimension of parish communion - as a fruit of the love of God the Father, the grace of our Lord Jesus Christ and the gift of unity in the Holy Spirit - creates incomparably richer and more effective support for its embodiment in a horizontal - interpersonal dimension than once integrated local community. However, this does not mean disregarding initiatives aimed at rebuilding the community-forming fabric of the parish in a structural dimension. The fruitful overcoming of the current crisis of the parish, associated with the civilization process of depersonalization of social bonds, presupposes concern for the constitution of smaller communities within it, as if "tailored to man."

John Paul II in the encyclical Redemptoris Missio explicitly recommends this type of solution, referring to "Christian base communities," which are a dynamic concept in mission areas (cf. $R M i, 51$ ). The same Pope, referring to the above question, formulates a clear postulate in the apostolic exhortation Christifideles laici, stating, inter alia, that if "all parishes may be truly communities of Christians," one must take care of creating "small, basic or so-called «living» communities, where the faithful can communicate the Word of God and express it in service and love to one another" $(C h L, 26) .{ }^{19}$ It should be added that the parish "community of communities" can be built not only "top-down" but also "bottom-up." In the structure of most parishes, smaller communities already have the form of various groups, associations, organi-

17 Cf. Makowski, "Postulat odnowy parafii," 204-205; Cf. Chevalier, La paroisse post-moderne; Vanzan Auletta, La parrocchia.

18 Cf. Hajduk, "Parafia," 51-55.

19 Cf. Żądło, "Drogi odnowy parafii," 151-152. 
zations and religious movements. It is then enough to revive, expand, deepen and coordinate their activities in the spirit of the ecclesiology of communion of the Second Vatican Council. ${ }^{20}$ This is the path to build the parish "community of communities," which John Paul II delineated for Polish pastoral ministry. ${ }^{21}$ Entering this path does not exclude, on the contrary, it assumes an attitude of openness to new opportunities and possibilities arising in this regard. One such opportunity is, for instance, as already mentioned in another context - a more fundamental appreciation of the real presence in the pastoral structure of the parish of family communities $(F C, 70)$. With this in mind, Benedict XVI did not hesitate to refer to the parish as "a family of Christian families."22

\section{Conclusion}

Each entity is characterized by its identity and action, and - according to the church principle of agere sequitur esse - action depends on the designated nature of the entity itself. In relation to church activity, it can be said that it results from spirituality, because it is spirituality, which is clearly defined, that determines the identity of a church entity. The communal nature of church communities does not result from the way they are organized. It is based on the spirituality of communion. Shaping this spirituality in church communities is one of the presbyter's basic pastoral tasks. Without such spirituality, any organizational activities will not express the communion character of the Church. They will refer to various principles of organization theory. Although these principles are also helpful in church activities, they do not convey the essence of church communion.

\section{Bibliography}

Biela, B., "Prezbiterat w służbie komunii w świetle posoborowego nauczania Kościoła," Studia Pastoralne 6 (2010) 33-45.

Chevalier, A., La paroisse post-moderne. Faire Église aujourd'hui. l'exemple du Quebec (Montreal: Éditions Paulines 1992).

Congregation for the Clergy, Directory Tota Ecclesia (1994) (= TE).

Francis, Exhortation Evangelii gaudium (2013) (=EG).

Gąsecki, K., "Prezbiter w kontekście eklezjologii komunijnej," Studia Gdańskie 26 (2010) 9-24.

\footnotetext{
20 Cf. Pluta, "Wspólnota parafialna," 93-98; Łaszczyk, "Stowarzyszenia," 296-304.

21 Cf. John Paul II, "Kościół wspólnotą," 16.

22 John Paul II, "Parafia wspólnotą," 20.
} 
Goddijn, H. - Goddijn, W., Sichtbare Kirche. Ökumene und Pastoral. Einführung in die Religionssoziologie (Wien: Herder 1967).

Hajduk, R., "Parafia jako «wspólnota wspólnot». Od teorii do praktyki," Homo Dei 76/1 (2007) 43-55.

John Paul II, Apostolic letter Novo millennio ineunte (2001) (= NMI).

John Paul II, Exhortation Christifideles laici (1988) (= ChL).

John Paul II, Exhortation Familiaris consortio (1981) (=FC).

John Paul II, Exhortation Pastores dabo vobis (1992) (= PDV).

John Paul II, Encyclical Redemptoris missio (1990) (= RMi).

John Paul II, "Kościół jako komunia po Pięćdziesiątnicy" [Catechesis delivered during the general audience, 05.02.1992], Wierzę w Kościót jeden, święty, powszechny i apostolski (Città del Vaticano: Libreria Editrice Vaticana - Edizioni Aquila Bianca 1996) 107-110.

John Paul II, “Kościół tajemnicą komunii zbudowanej na miłości [Catechesis delivered during the general audience, 15.01.1992], Wierze w Kośció jeden, święty, powszechny i apostolski (Città del Vaticano: Libreria Editrice Vaticana - Edizioni Aquila Bianca 1996) 99-102.

John Paul II, "Kościół wspólnotą ewangelizującą" [Address to the Ist group of Polish bishops as part of "ad limina Apostolorum" visit, 12.01.1993], L'Osservatore Romano [Polish edition] 14/2 (1993) 12-18.

John Paul II, "Parafia wspólnotą zjednoczoną w Chrystusie" [Address to participants of the plenary meeting of the Pontifical Council for the Laity, 22.09.2006], L'Osservatore Romano [Polish edition] 27/12 (2006) 19-20.

John Paul II, “U źródeł komunii kościelnej” [Catechesis delivered during the general audience, 29.01.1992], Wierzę w Kościót jeden, święty, powszechny i apostolski (Città del Vaticano: Libreria Editrice Vaticana - Edizioni Aquila Bianca 1996) 103-106.

John Paul II, "Więzi prezbiterów z innymi wiernymi" [Catechesis delivered during the general audience, 29.09.1993], Wierzę w Kościól jeden, święty, powszechny i apostolski (Città del Vaticano: Libreria Editrice Vaticana - Edizioni Aquila Bianca 1996) 344-348.

Kasper, W., Kościół katolicki. Istota - rzeczywistość - posłannictwo (Kraków: WAM 2014).

Łaszczyk, M., "Stowarzyszenia i ruchy eklezjalne jako szansa urzeczywistniania się Kościoła w parafialnej wspólnocie," Studia Włocławskie 6 (2003) 296-304.

Makowski, T., "Postulat odnowy parafii w kontekście pastoralnych wyzwań nowej ewangelizacji," Studia Gnesnensia 21 (2007) 169-222.

Pannet, R., La paroisse de l’avenir. L’avenir de la paroisse (Paris: Fayard 1979).

Piwowarski, W., "Próby rekonstrukcji wspólnoty parafialnej," Znak 21/10 (1969) 1311-1320.

Pluta, W., "Wspólnota parafialna i jej zespoły apostolskie," Roczniki Teologiczno-Kanoniczne 32/6 (1985) 93-98.

Polak, M., Prezbiterologia pastoralna. Pastoralna tożsamość współczesnego prezbitera (Poznań: Wydawnictwo Wydziału Teologicznego UAM 2016).

Rahner, K., "Friedliche Erwägungen über das Pfarrprinzip," Zeitschrift für katholische Theologie 70/2 (1948) 169-198.

Ratzinger, J., Pielgrzymująca wspólnota wiary. Kościół jako komunia (Kraków: Wydawnictwo M 2003).

Vatican II, Constitution Lumen gentium (1964) (=LG).

Vatican II, Constitution Sacrosanctum Concilium (1963) (=SC). 


\section{MIECZYSŁAW POLAK}

Vatican II, Decree Presbyterorum ordinis (1965) (=PO).

Thomas, P., Que devient la paroisse? Mort annoncée on nouveau visage? (Paris: Desclée de Brouwer 1996).

Vanzan, P. - Auletta, A., La parrocchia per la nuova evangelizzazione: tra corresponsabilità e partecipazione (Roma: AVE 1998).

Żądło, A., "Drogi odnowy parafii w duchu Soboru Watykańskiego II,” Przegląd Pastoralno-Homiletyczny 3 (1999) 135-162. 